\title{
Effect of Fatigue Load on Internal Mechanical Properties of the Intervertebral Disc
}

\author{
Efecto de la Carga de Fatiga en las Propiedades Mecánicas Internas del Disco Intervertebral
}

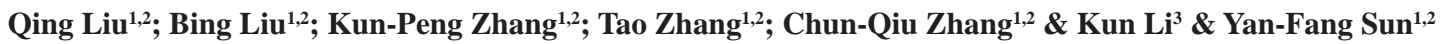

LIU, Q.; LIU, B.; ZHANG, K. P.; ZHANG, T.; ZHANG, C. Q. \& LI, K. \& SUN, Y. F. Effect of fatigue load on internal mechanical properties of the intervertebral disc. Int. J. Morphol., 38(6):1597-1605, 2020.

SUMMARY: Lumbar disc herniation is considered to be the main pathological factor for the common clinical disease of low back pain. Biomechanical factor is an important cause of lumbar disc herniation, so it is urgent to analyze the stress/strain behavior of intervertebral disc under different loading condition. Slow repetitive loading is considered to be an important factor of spine and disc injuries, and the effect of fatigue load on internal displacement in the intervertebral disc was investigated by applying the optimized digital image correlation technique in this study. The first finding was that fatigue load had a significant effect on the displacement distribution in the intervertebral disc under compression. Superficial AF exhibited the largest axial displacements before fatigue load, while it exhibited the smallest axial displacements after fatigue load. Inner AF exhibited slightly smaller radial displacements than outer AF before fatigue load, while it exhibited significantly greater radial displacements than outer AF displacements after fatigue load. The second finding was that fatigue load had a certain effect on the internal displacement distribution in the flexed intervertebral disc under compression. Middle AF exhibited the smallest axial displacements before fatigue load, while deep AF exhibited the smallest axial displacements after fatigue load. The radial displacement distribution did not change before and after fatigue load, as the radial displacement in outer AF was the smallest, while the radial displacement in inner AF was the largest. The third finding was that with the increase in fatigue time and amplitude, the Young's modulus of the intervertebral disc increased significantly. This study can provide the basis for clinical intervertebral disc disease prevention and treatment?and is important for mechanical function evaluation of artificial intervertebral disc as well.

KEY WORDS: Lumbar disc herniation; Fatigue; Forward flexion; Internal displacement; Optimized DIC technique.

\section{INTRODUCTION}

Lumbar Disc Herniation (LDH) is considered to be the main pathological factor for the common clinical disease of low back pain (Sapiee et al., 2019). Epidemiological investigations show that there is a higher incidence in people who are overworked and under heavy workload (van Heeswijk et al., 2018). Lumbar disc herniation is generally considered to be a cumulative injury, that repetitive loading may cause the nucleus pulposus to penetrate the anulus fibrosus, and eventually extrude posteriorly (Köksal et al., 2020). It is unclear how likely the nucleus herniation is caused when the fissure in the fibrous ring is large enough. However, once the fissure is formed, there is a risk of lumbar disc herniation. Biomechanical factor is an important cause of lumbar disc herniation, so it is urgent to analyze the stress/strain behavior of intervertebral disc under different loading condition (Wade et al., 2017).

Epidemiological studies have found that slow repetitive loading is considered to be the most important factor of spine and disc injuries (Thoreson et al., 2017). Lumbar intervertebral disc fatigue injury, characterized as the initiation of micro-cracks, is a minor damage to the intervertebral disc under a certain intensity of fatigue load. The accumulation of long-term minor injuries will eventually lead to a serious lumbar spine disease due to a small inducement. There are many clinical cases of lumbar disc herniation that seem to be caused by sudden

\footnotetext{
${ }^{1}$ Tianjin Key Laboratory for Advanced Mechatronic System Design and Intelligent Control, Tianjin University of Technology, Tianjin 300384, PR China. ${ }^{2}$ National Demonstration Center for Experimental Mechanical and Electrical Engineering Education, Tianjin University of Technology, Tianjin 300384, PR China.

${ }^{3}$ Tianjin Key Laboratory of Film Electronic and Communication Device, Tianjin University of Technology, Tianjin 300384, PR China.
} 
excessive load, but the actual cause is fatigue injury (Veres et al., 2010). Some scholars have performed in vitro experiments using animal models to study the effect of fatigue damage on the mechanical properties of lumbar discs. For example, Schollum et al. (2018) subjected ovine lumbar intervertebral discs to 5000 cycles at $0.5 \mathrm{~Hz}$ with a peak load corresponding to $30 \%$ of that required to achieve failure, then investigated microstructural of low frequency cyclic loading and flexing of the lumbar disc. BergerRoscher et al. (2017), used a newly developed 6-degreeof-freedom disc loading simulator to perform the cyclic complex loading, and investigated how different loading combinations influence the mechanism and extent of intervertebral disc failure. Most of the current studies have observed macroscopic evidence of fatigue failure. However, few studies have discussed morphological changes in vertebral discs due to fatigue testing, which are essential to better understand the process of lumbar disc herniation caused by the fissure in the anulus fibrosus.

The intervertebral disc is subjected to complex loading conditions (Hareni et al., 2019). In fact, even simple axial compression creates complex load conditions on the intervertebral disc through the circumferential tensile stress of the anulus fibrosus, radial bulging of the anulus fibrosus, and the interaction between the nucleus pulposus and the surrounding anulus fibrosus ( $\mathrm{O}^{\prime}$ Connell et al., 2011). Existing research shows that cyclically loaded compressive load will always damage the vertebral body, while cyclically loaded compression load combined with axial rotation or bending may cause damage to the anulus fibrosus (Benzakour \& Benzakour, 2020). Some scholars used the finite element method to study the biomechanical characteristics of the intervertebral disc, considering the effects of load form, degeneration, and clinical application. For example, Casaroli et al. (2017) established a finite element simulation model of ovine lumbar intervertebral discs and performed numerical analysis under combined load conditions, then explored which mechanical condition may cause intervertebral disc damage. Azarnoosh et al. (2018) established a finite element simulation model of pig lumbar intervertebral discs, and used the pseudo-elastic damage model to describe the anisotropic mechanical damage behavior of intervertebral discs. However, the existing finite element study of the intervertebral disc is difficult to be validated due to the lack of experimental data.

In this study, fatigue compressive loading was applied to the intervertebral disc to simulate a day's heavy labor, and the effect of fatigue load on internal displacement in the intervertebral disc was investigated by applying the optimized digital image correlation (DIC) technique. Simultaneously the effects of fatigue amplitude and fati- gue time on the overall mechanical properties of the intervertebral disc have also been analyzed.

\section{MATERIAL AND METHOD}

Materials: 20 lumbar spines from 8-month-old sheep were obtained immediately after sacrificing, and the L3-4 motion segments were isolated. The excess soft tissue and muscle tissue were removed, with the vertebral bodies of approximately $4 \mathrm{~mm}$ retained. The elliptic area of the IVD was obtained by measuring the length and width of the disc and multiplied, from which the disc area $S=400 \pm 10$ $\mathrm{mm}^{2}$, and the height $\mathrm{h}=4 \pm 0.12 \mathrm{~mm}$. The 20 test samples were divided into two groups, of which 10 samples were used for the overall mechanical performance test and 10 samples were used for the internal mechanical performance test. The 10 samples for the internal mechanical performance test were cut parallel to the sagittal plane, and the nucleus pulposus were not damaged to maintain the internal pressure. Before the experiment, all the samples were wrapped with gauze containing normal saline so as to maintain the humidity of the intervertebral disc.

Experimental apparatus. The fatigue test of the intervertebral disc was performed on a EUT-1020 electronic universal fatigue testing machine (Center of Mechanical Experiment in Shanghai University, China). The machine mainly consists of the computer control system, the mechanical loading device, the image acquisition system, and the image processing software. The load capacity of the mechanical loading device is $1 \mathrm{KN}$, and the stroke is $\pm 100 \mathrm{~mm}$. The progressive scan CCD camera is applied for the image acquisition system, with the accuracy of $1376 \times 1035$ and the maximum magnification of 300 times. The image processing software can be used to process the captured sequential images to obtain the displacement fields. Figure 1 shows the experimental setup for the intervertebral disc.

Methods. This experiment was to test the change of quasistatic compression performance of lumbar intervertebral disc before and after fatigue load. The quasi-static compression rate were adjusted to $0.1 \mathrm{~mm} / \mathrm{s}$ (strain rate of $0.025 / \mathrm{s}$ ), and the stop displacement were adjusted to $1 \mathrm{~mm}$ (strain of 30 $\%)$. At room temperature, the L3-4 segment was fatigue loaded with an electronic universal fatigue testing machine (EUT-1020) at a frequency of $0.5 \mathrm{~Hz}$. The fatigue time was set to $1 \mathrm{~h}, 2 \mathrm{~h}, 3 \mathrm{~h}, 4 \mathrm{~h}$, while the fatigue amplitude was set to $150 \mathrm{~N}, 300 \mathrm{~N}, 450 \mathrm{~N}$ and $600 \mathrm{~N}$. There were two types of fixing methods: vertical fixing method and forward flexion fixing method. Before and after fatigue load, quasi-static 


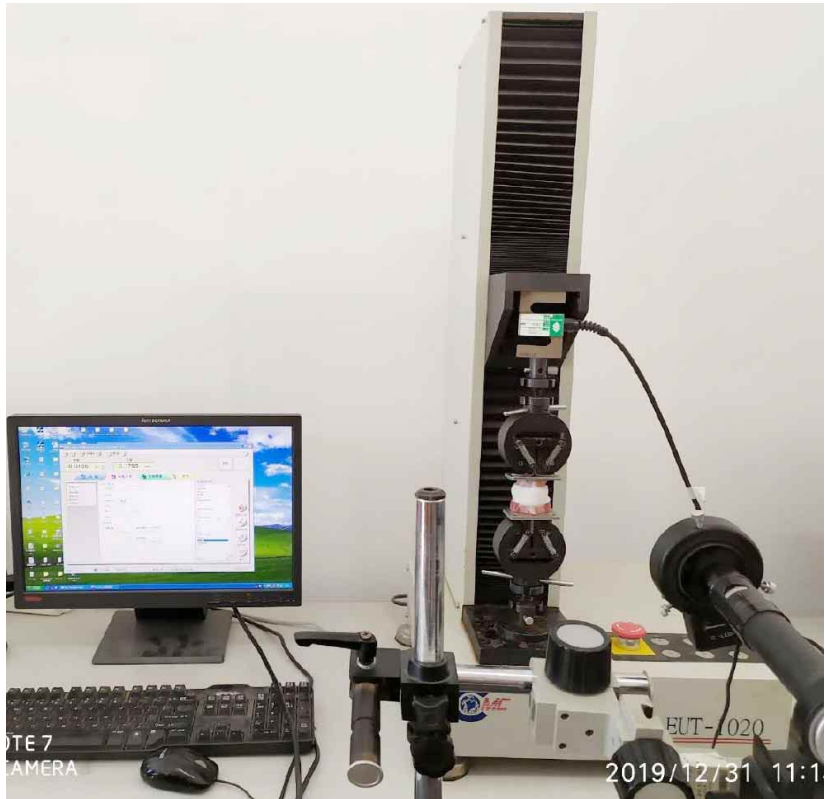

Fig. 1 Experimental apparatus.

compression was performed on the fixed experimental samples, in order to test the effect of fatigue load on the quasi-static mechanical properties of the intervertebral disc.

The optimized DIC technique was used as the experimental method, and iron oxide nanoparticles were uniformly applied on the cut surface as the mark points to reflect the deformation in different regions of the intervertebral disc. After the test, the displacement field was obtained using image processing software. Figure 2 showed local region with evenly distributed nanoparticles in the incision surface of the lumbar intervertebral disc before and after quasi-static loading. A pair of marked points $a_{1}\left(\mathrm{x}_{1}, \mathrm{y}_{1}\right)$ and $a_{2}\left(x_{2}, y_{2}\right)$ with similar $\mathrm{x}$ value were selected, and the axial displacement distribution will be reflected by comparing the $y$ value between this pair of points before and after loading. A pair of marked points $a_{3}$ $\left(x_{3}, y_{3}\right)$ and $a_{4}\left(x_{4}, y_{4}\right)$ with similar y value were selected, and the radial displacement distribution will be reflected by comparing the $\mathrm{x}$ value between this pair of points before and after loading.

Statistical analysis. A one-way analysis of variance (ANOVA) with repeated measures was performed to detect the differences among the experimentally measured values of the strain as well as the displacement in the compression tests. Statistical significance was accepted for pb0.05. Data points in the figures represent mean values, whereas error bars indicate the standard errors above and below corresponding mean values.

\section{RESULTS}

Effects of fatigue loading on mechanical properties of the intervertebral disc under compression. Figure 3 showed the axial displacement in the intervertebral disc under compression before and after fatigue loading, with a loading rate of $0.1 \mathrm{~mm} / \mathrm{s}$. It could be seen from the figure that the displacement in different regions of the intervertebral disc did not coincide, indicating that mechanical properties in different regions were different. Superficial AF exhibited the largest axial displacements before fatigue load, while it exhibited the smallest axial displacements after fatigue load.

Figure 4 showed the radial displacement in the intervertebral disc under compression before and after fatigue loading, with a loading rate of $0.1 \mathrm{~mm} / \mathrm{s}$. It was found that, inner AF exhibited slightly smaller radial displacements than outer AF before fatigue load, while it exhibited significantly greater radial displacements than outer AF displacements after fatigue load.
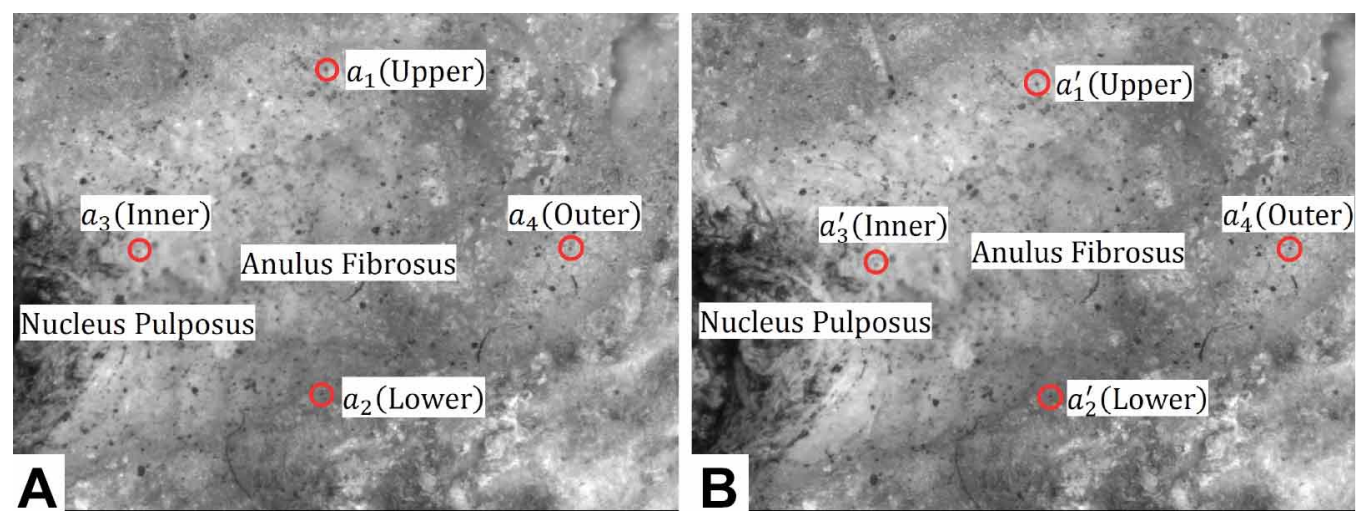

Fig. 2 Images collected by digital image correlation system. A. Before quasi-static compression. B. After quasi-static compression. 

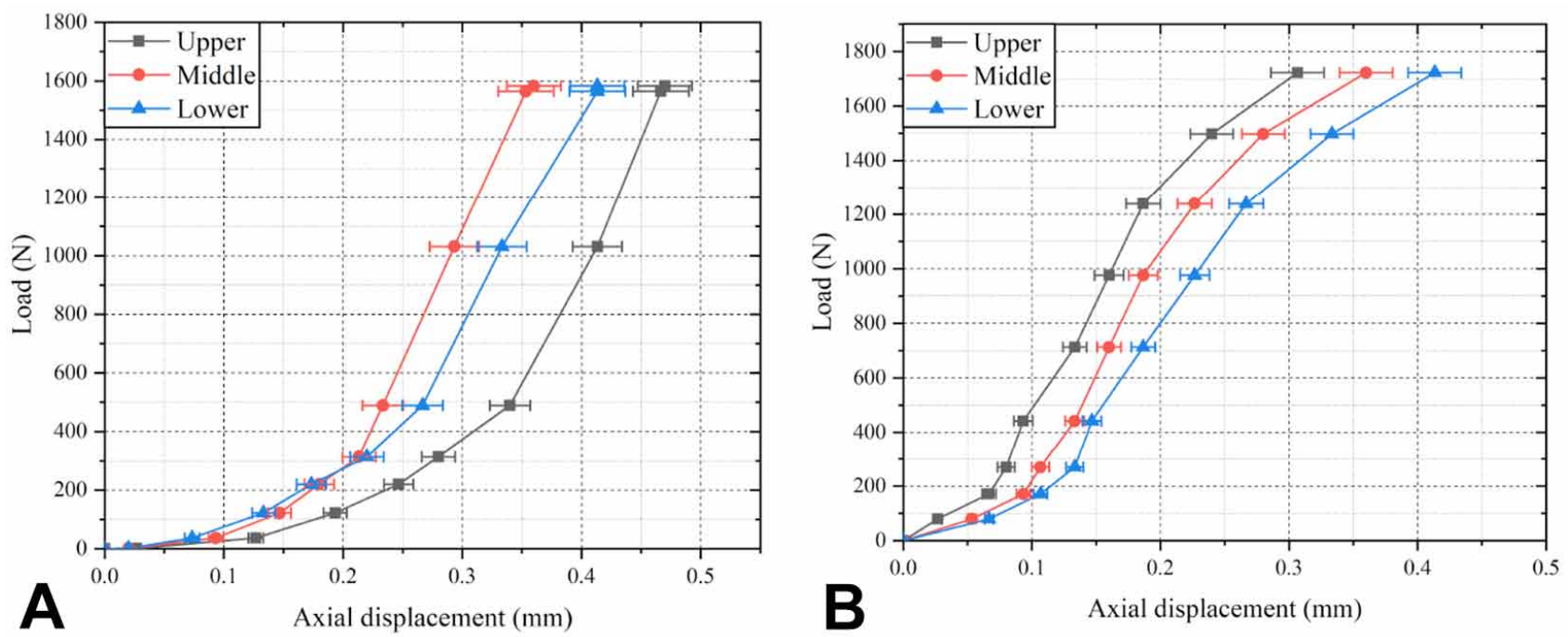

Fig. 3 Axial displacement in the intervertebral disc under compression. A. Before fatigue load. B. After fatigue load.
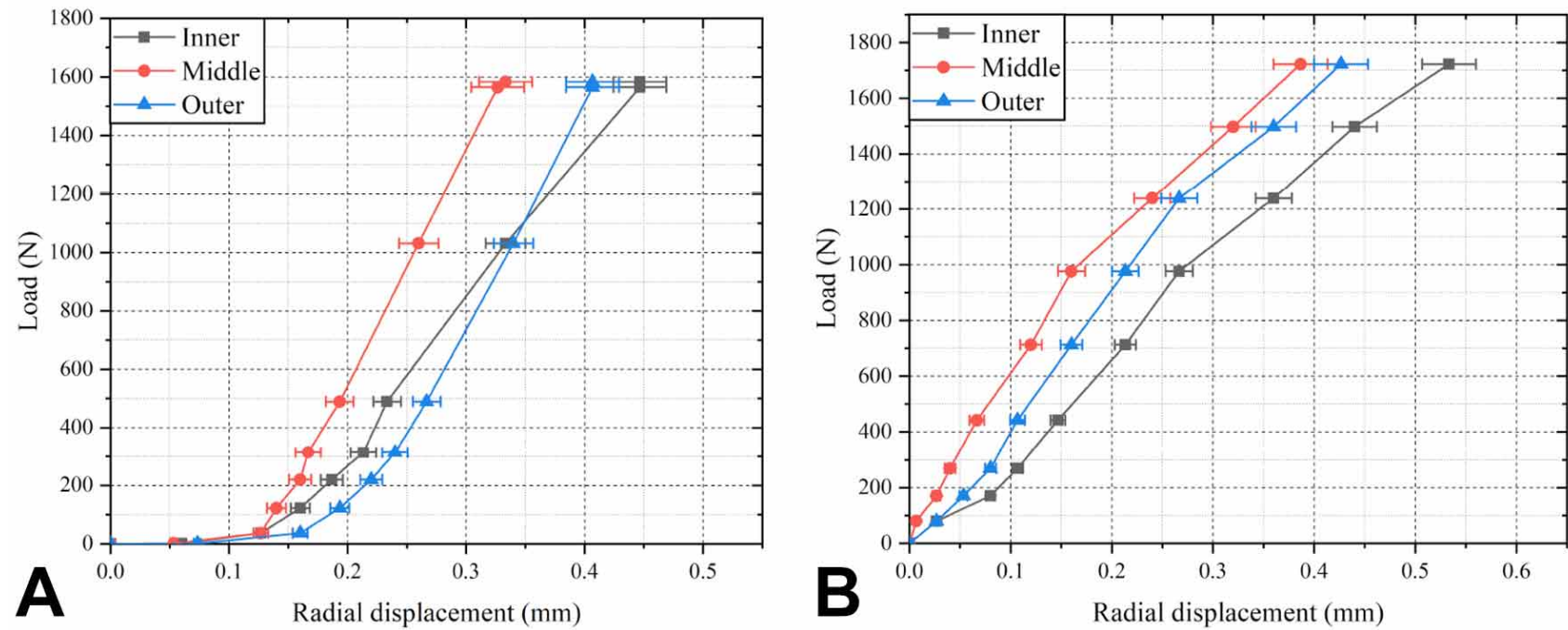

Fig.4 Radial displacement in the intervertebral disc under compression. A. Before fatigue load. B. After fatigue load.

Figure 5 showed the effect of fatigue load on the overall mechanical properties of the intervertebral disc under compression. It was noted that all samples demonstrated a nonlinear stress-strain profile before and after fatigue loading. However, once the sample was deformed beyond its toe region, it demonstrated an elastic region. According to the stress-strain profile, the Young's modulus in the elastic region is calculated, as shown in Table I and II. The results showed that, with the increase in fatigue time and amplitude, the Young's modulus of the intervertebral disc increased significantly.

Effects of fatigue loading on mechanical properties of the flexed intervertebral disc under compression. Fi- gure 6 showed the axial displacement in the flexed intervertebral disc under compression before and after fatigue loading, with a loading rate of $0.1 \mathrm{~mm} / \mathrm{s}$. It could be seen from the figure that the displacement in different regions of the intervertebral disc did not coincide, indicating that mechanical properties in different regions were different. Middle AF exhibited the smallest axial displacements before fatigue load, while deep AF exhibited the smallest axial displacements after fatigue load.

Figure 7 showed the distribution of the radial displacement inside the dorsal fiber ring under forward flexion compression before and after fatigue loading, with 
a loading rate of $0.1 \mathrm{~mm} / \mathrm{s}$. The radial displacement distribution did not change before and after fatigue load,

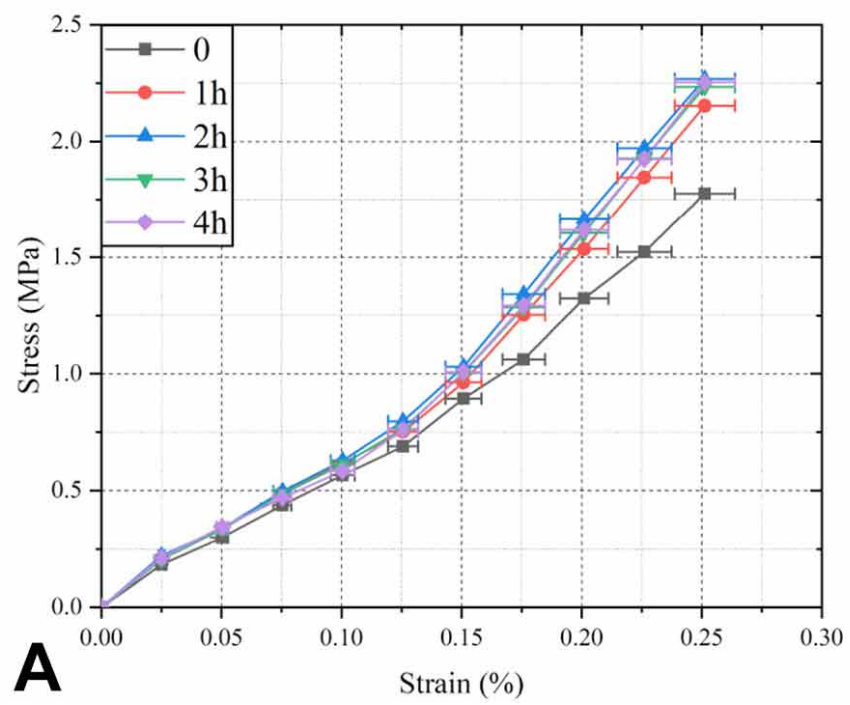

as the radial displacement in outer AF was the smallest, while the radial displacement in inner AF was the largest.

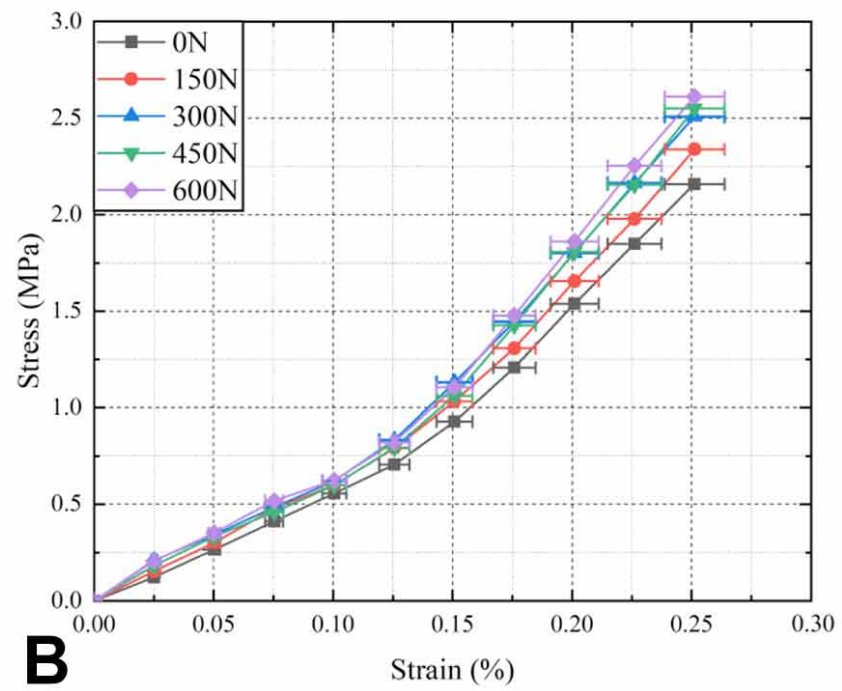

Fig. 5 Effect of fatigue load on the overall mechanical properties of the intervertebral disc under compression. A. Effect of fatigue time. B. Effect of fatigue amplitude.
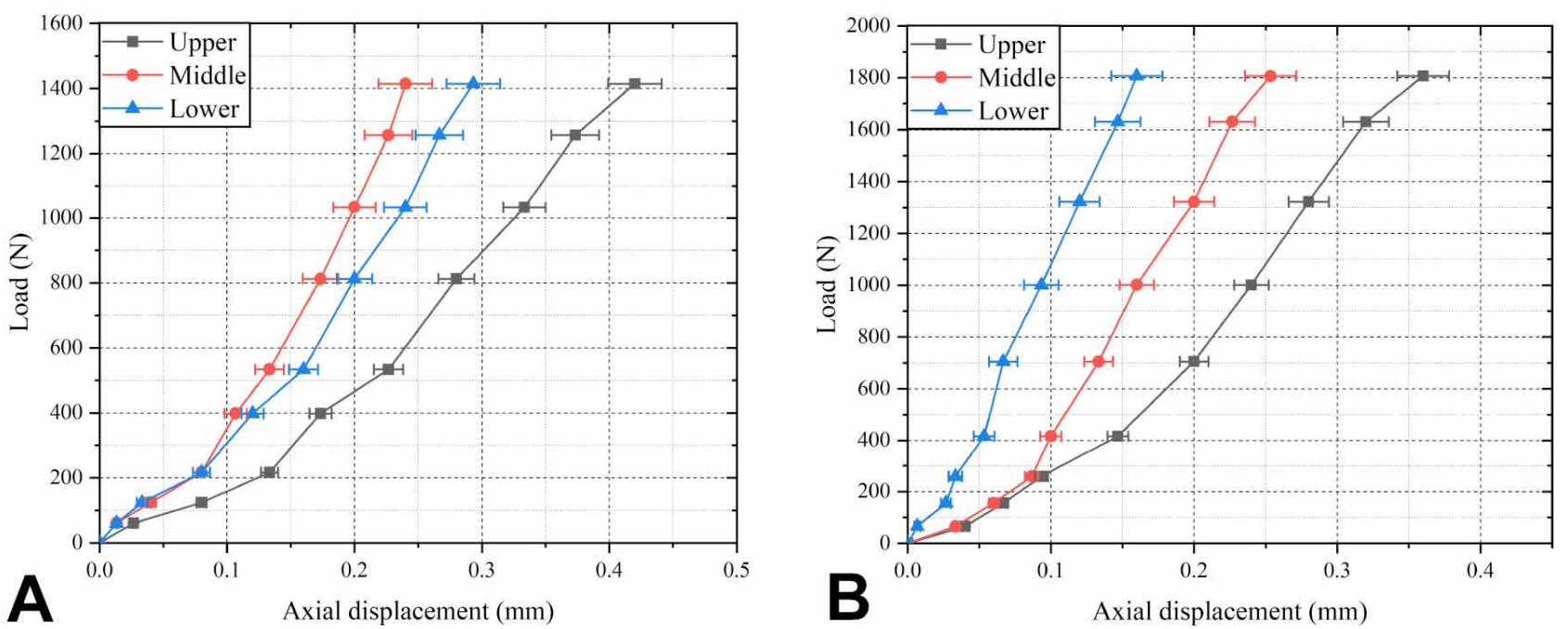

Fig. 6 Axial displacement in the flexed intervertebral disc under compression. A. Before fatigue load. B. After fatigue load.

Table I. The effect of changes in fatigue time on the overall mechanical properties of the intervertebral disc under compression.

\begin{tabular}{cccc}
\hline Sample & $\begin{array}{c}\text { Fatigue } \\
\text { amplitude } \\
(\mathrm{N})\end{array}$ & $\begin{array}{c}\text { Fatigue } \\
\text { time } \\
(\mathrm{h})\end{array}$ & $\begin{array}{c}\text { Young's } \\
\text { modulus } \\
(\mathrm{MPa})\end{array}$ \\
\hline \multirow{3}{*}{ L3-4 } & \multirow{3}{*}{300} & 0 & 8.66 \\
& & 1 & 11.16 \\
& & 2 & 11.72 \\
& 3 & 11.70 \\
& 4 & 11.90 \\
\hline
\end{tabular}

Table II. The effect of changes in fatigue amplitude on the overall mechanical properties of the intervertebral disc under compression.

\begin{tabular}{cccc}
\hline Sample & $\begin{array}{c}\text { Fatigue } \\
\text { time } \\
(\mathrm{h})\end{array}$ & $\begin{array}{c}\text { Fatigue } \\
\text { amplitude } \\
(\mathrm{N})\end{array}$ & $\begin{array}{c}\text { Young's } \\
\text { modulus } \\
(\mathrm{MPa})\end{array}$ \\
\hline \multirow{3}{*}{ L3-4 } & 1 & 0 & 11.58 \\
& & 150 & 12.33 \\
& & 300 & 13.33 \\
& 450 & 13.99 \\
& 600 & 14.25 \\
\hline
\end{tabular}



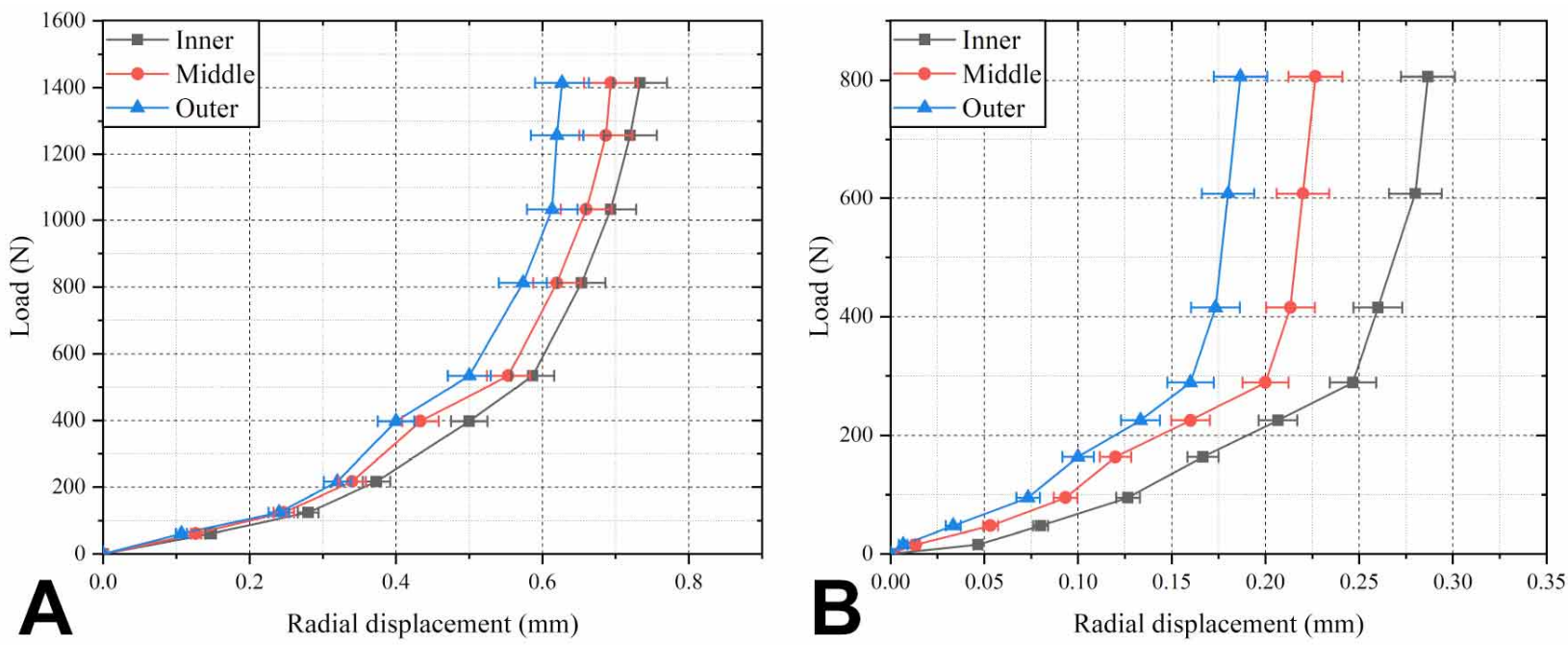

Fig. 7 Radial displacement in the flexed intervertebral disc under compression. A. Before fatigue load. B. After fatigue load.

Figure 8 showed the effect of fatigue load on the overall mechanical properties of the flexed intervertebral disc under compression. It was noted that all samples demonstrated a nonlinear stress-strain profile before and after fatigue loading. However, once the sample was deformed beyond its toe region, it demonstrated an elastic region.

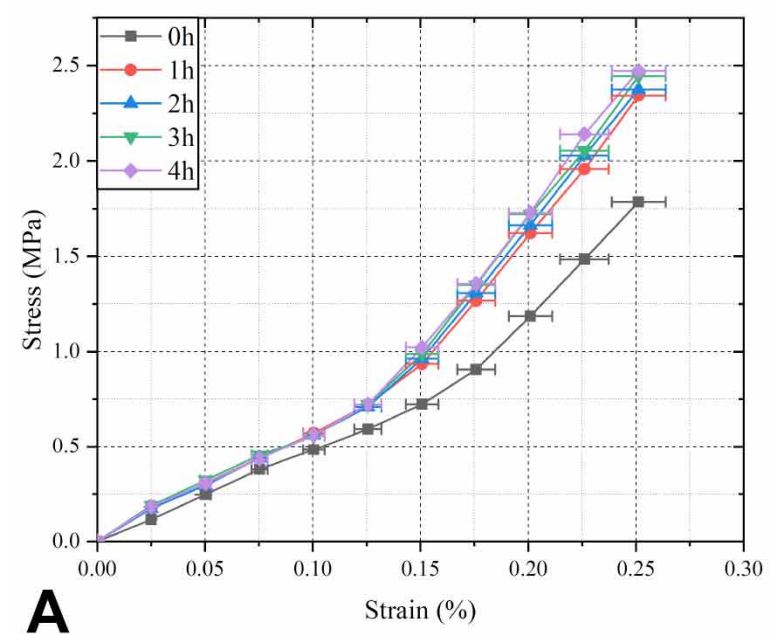

According to the stress-strain profile, the Young's modulus in the elastic region is calculated, as shown in Table III and IV. The results showed that, with the increase in fatigue time and amplitude, the Young's modulus of the intervertebral disc increased significantly.

Fig. 8 Effect of fatigue load on the overall mechanical properties of the flexed intervertebral disc under compression. A. Effect of fatigue time. B. Effect of fatigue amplitude.

Table III. Effect of fatigue time on the overall mechanical properties of the flexed intervertebral disc under compression.

\begin{tabular}{cccc}
\hline Sample & $\begin{array}{c}\text { Fatigue } \\
\text { amplitude } \\
(\mathrm{N})\end{array}$ & $\begin{array}{c}\text { Fatigue } \\
\text { time } \\
(\mathrm{h})\end{array}$ & $\begin{array}{c}\text { Young's } \\
\text { modulus } \\
(\mathrm{MPa})\end{array}$ \\
\hline \multirow{3}{*}{ L3-4 } & & 0 & 9.48 \\
& \multirow{3}{*}{300} & 1 & 12.90 \\
& & 2 & 13.25 \\
& & 3 & 13.71 \\
& & 4 & 13.93 \\
\hline
\end{tabular}

Table IV. Effect of fatigue amplitude on the overall mechanical properties of the flexed intervertebral disc under compression.

\begin{tabular}{cccc}
\hline Sample & $\begin{array}{c}\text { Fatigue } \\
\text { time } \\
(\mathrm{h})\end{array}$ & $\begin{array}{c}\text { Fatigue } \\
\text { amplitude } \\
(\mathrm{N})\end{array}$ & $\begin{array}{c}\text { Young's } \\
\text { modulus } \\
(\mathrm{MPa})\end{array}$ \\
\hline \multirow{3}{*}{ L3-4 } & & 0 & 8.45 \\
& 1 & 150 & 11.59 \\
& & 300 & 12.18 \\
& & 450 & 13.88 \\
& 600 & 14.64 \\
\hline
\end{tabular}




\section{DISCUSSION}

The purpose of this study was to investigate the effect of fatigue load on the intervertebral disc by applying an optimized DIC technique.

The first finding was that fatigue load had a significant effect on the axial displacement distribution in the intervertebral disc under compression. Superficial AF exhibited the largest axial displacements before fatigue load, while it exhibited the smallest axial displacements after fatigue load. This result was in good agreement with the result of Gooyers \& Callaghan (2015), who found that the relative contribution of disc height loss to total sample height loss varies widely during the entire experimental conditions, ranging from $19 \%$ to $58 \%$. When the intervertebral disc is subjected to a long-term high-level axial load, such as standing for a long time, the tissue will squeeze the interstitial water out of the intervertebral disc, so the disc height is reduced and lumbar disc herniation may occur. This may lead to changes in the axial displacement distribution in the intervertebral disc (Liu et al., 2017).

In addition, fatigue load had a certain effect on the radial displacement distribution in the intervertebral disc under compression. Inner AF exhibited slightly smaller radial displacements than outer AF before fatigue load, while it exhibited significantly greater radial displacements than outer AF displacements after fatigue load. The intervertebral disc is constructed of a central gel-like nucleus pulposus surrounded by a peripheral firm annulus fibrosus, these tissues play different roles in the biomechanical function of the intervertebral disc (Flouzat-Lachaniette et al., 2018). Outer AF can resist tensile load and surround inner AF, while the nucleus pulposus can provide a hydrostatic barrier to limit the deformation (Vadalà et al., 2018). Some scholars have proposed the hypothesis for the fatigue mechanism of the intervertebral disc, based on the specific property of the hydraulic effect of the nucleus pulposus. They believed that it is caused by the penetration of the damaged nucleus pulposus into the endplate and the fibrous rings, so the fibrous rings bulge outward during fatigue loading. They believe that the damage is caused by the nucleus pulposus penetrating into the endplate and the annulus fibrosus, so the annulus fibrosus bulge outward during fatigue loading, which may cause changes in the radial displacement distribution in the intervertebral disc (Freutel et al., 2014; Schmidt et al., 2014).

The second finding was that fatigue load had a certain effect on the internal displacement distribution in the flexed intervertebral disc under compression. Middle AF exhibited the smallest axial displacements before fatigue load, while deep AF exhibited the smallest axial displacements after fatigue load. This result was in good agreement with the result of Schollum et al., who have found that the intervertebral disc damage was limited to the inner layer deformation and small stratification at 5000 cycles. Besides, the radial displacement distribution did not change before and after fatigue load, as the radial displacement in outer AF was the smallest, while the radial displacement in inner $\mathrm{AF}$ was the largest. An increase in the spinal pressure during anterior flexion will lead to an increase in the pressure of lumbar nucleus pulposus, which may cause the initiation and progression of tears in annulus fibrosus adjacent to the nucleus pulposus, thereby causing lumbar disc herniation (Dao, 2016). In addition, the nucleus pulposus moves towards the posterior region during forward flexion, which may partially support the load in the region and reduce strain. However, posterior AF includes lower circumferential tensile moduli and thinner lamellae compared to anterior AF, which tends to increase the inner layer displacement in posterior AF (Dao, 2017).

The third finding was that fatigue load had a significant effect on the overall mechanical properties of the intervertebral disc under compression as well as forward flexion. In addition, there are significant differences in the mechanical properties of the intervertebral disc during compression and forward flexion. Figure 9 is the force analysis of the lumbar spine when the human body bend over to lift weights. $\theta$ is the forward flexion angle, $F_{N}$ is the spine pressure. $F_{e}$ is the extensor force, and a is the arm of $F_{e} \cdot W_{l}$ is the gravity of the heavy object, and $\mathrm{b}$ is the arm of $\mathrm{W} 1$. W is the gravity of the upper body of a human, and $\mathrm{c}$ is the arm of $W$.

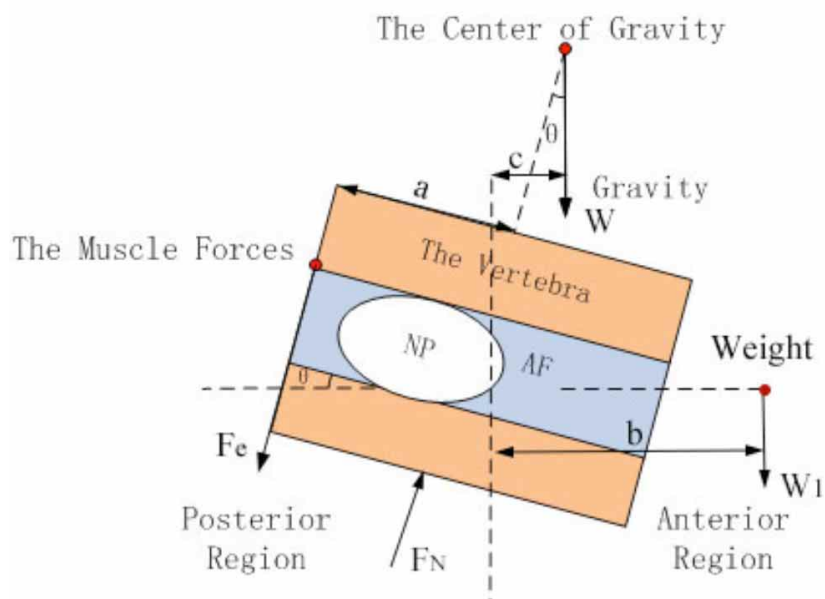

Fig. 9. Force analysis of the lumbar spine when the human body bend over to lift weights.

Based on the moment balance, the extensor force can be calculated: 


$$
F_{e}=\left(W_{1} b+W c\right) / a
$$

Based on the force balance, the spinal pressure can be calculated:

$$
F_{N}=F_{e}+\left(W+W_{1}\right) \cos \theta
$$

Based on formulas (1)-(2), the pressure in the lumbar intervertebral disc when the human body bends to lift a weight can be calculated, as shown in Table V. The results show that with only $10^{\circ}$ forward flexion, if a $300 \mathrm{~N}$ weight is carried, the pressure FN in the lumbar intervertebral disc can increase to several times the weight. The above analysis results show that when the human body bends and lifts heavy objects, slight movement will cause great pressure on the intervertebral disc, which may cause rupture in the intervertebral disc after fatigue injury.

Table V. Lumbar intervertebral disc force when the human body bends to lift heavy objects.

\begin{tabular}{ccccc}
\hline Sample & $\begin{array}{c}\text { Forward flexion } \\
\text { angle }\end{array}$ & $\begin{array}{c}\text { Weight } \\
W_{l}(\mathrm{~N})\end{array}$ & $\begin{array}{c}\text { Extensor } \\
\text { force } \\
F_{e}(\mathrm{~N})\end{array}$ & $\begin{array}{c}\text { Spine } \\
\text { Pressure } \\
F_{N}(\mathrm{~N})\end{array}$ \\
\hline \multirow{3}{*}{ L3-L4 } & $10^{\circ}$ & 100 & 1800 & 2391 \\
& & 300 & 3800 & 4588 \\
& & 500 & 5800 & 6785 \\
\hline
\end{tabular}

\section{ACKNOWLEDGEMENTS}

The project was partly supported by the National Natural Science Foundation of China (No.11802207) and Science Foundation of Tianjin (No. 18YFZCSY00890, 18ZXSGSY00010).

LIU, Q.; LIU, B.; ZHANG, K. P.; ZHANG, T.; ZHANG, C. Q. \& LI, K. \& SUN, Y. F. Efecto de la carga de fatiga en las propiedades mecánicas internas del disco intervertebral. Int. J. Morphol., 38(6):1597-1605, 2020.

RESUMEN: La hernia de disco lumbar se considera el principal factor patológico para la enfermedad clínica común del dolor lumbar. El factor biomecánico es una causa importante de hernia de disco lumbar, por lo que es urgente analizar el comportamiento de esfuerzo / tensión del disco intervertebral bajo diferentes condiciones de carga. La carga repetitiva lenta se considera un factor importante de lesiones de columna y disco, y en este estudio el efecto de la carga de fatiga sobre el desplazamiento interno en el disco intervertebral se investigó mediante la aplicación de la técnica de correlación de imagen digital optimizada. El primer hallazgo fue que la carga de fatiga tuvo un efecto significativo en la distri- bución del desplazamiento en el disco intervertebral bajo compresión. El AF superficial exhibió los desplazamientos axiales más grandes antes de la carga de fatiga, mientras que exhibió los desplazamientos axiales más pequeños después de la carga de fatiga. El AF interno exhibió desplazamientos radiales ligeramente más pequeños que el AF externo antes de la carga de fatiga, mientras que exhibió desplazamientos radiales significativamente mayores que los desplazamientos AF externos después de la carga de fatiga. El segundo hallazgo fue que la carga de fatiga tenía un cierto efecto sobre la distribución del desplazamiento interno en el disco intervertebral flexionado bajo compresión. El AF medio exhibió los desplazamientos axiales más pequeños antes de la carga de fatiga, mientras que el AF profundo exhibió los desplazamientos axiales más pequeños después de la carga de fatiga. La distribución del desplazamiento radial no cambió antes ni después de la carga de fatiga, ya que el desplazamiento radial en la FA externa fue el más pequeño, mientras que el desplazamiento radial en la FA interna fue el más grande. El tercer hallazgo fue que con el aumento del tiempo de fatiga y la amplitud, el módulo de Young del disco intervertebral aumentó significativamente. Este estudio puede proporcionar la base para la prevención y el tratamiento clínico de la enfermedad del disco intervertebral, y también es importante para la evaluación de la función mecánica del disco intervertebral artificial.

PALABRAS CLAVE: Hernia de disco lumbar, Fatiga, Flexión delantera, Desplazamiento interno, Técnica DIC optimizada.

\section{REFERENCES}

Azarnoosh, M.; Stoffel, M. \& Markert, B. A study of the damage behaviour of porcine intervertebral discs in a bioreactor environment. J. Mech. Behav. Biomed. Mater, 77:727-33, 2018.

Benzakour, A. \& Benzakour, T. Lumbar disc herniation: long-term outcomes after mini-open discectomy. Int. Orthop., 44(2):409, 2020.

Berger-Roscher, N.; Casaroli, G.; Rasche, V.; Villa, T.; Galbusera, F. \& Wilke, H. J. Influence of complex loading conditions on intervertebral disc failure. Spine (Phila Pa 1976), 42(2):E78-85, 2017.

Casaroli, G.; Villa, T.; Bassani, T.; Berger-Roscher, N.; Wilke, H. J. \& Galbusera, F. Numerical prediction of the mechanical failure of the intervertebral disc under complex loading conditions. Materials (Basel), 10(1):31, 2017.

Dao, T. T. Enhanced musculoskeletal modeling for prediction of intervertebral disc stress within annulus fibrosus and nucleus pulposus regions during flexion movement. J. Med. Biol. Eng., 36(4):583-93, 2016.

Dao, T. T. Hybrid rigid-deformable model for prediction of neighboring intervertebral disk loads during flexion movement after lumbar interbody fusion at L3-4 Level. J. Biomech. Eng., 139(3), 2017. DOI: https://www.doi.org/10.1115/1.4035483

Flouzat-Lachaniette, C. H.; Jullien, N.; Bouthors, C.; Beohou, E.; Laurent, B.; Bierling, P.; Dubory, A.A novel in vivo porcine model of intervertebral disc degeneration induced by cryoinjury. Int. Orthop., 42(9):2263-72, 2018.

Freutel, M.; Schmidt, H.; Dürselen, L.; Ignatius, A. \& Galbusera, F. Finite element modeling of soft tissues: material models, tissue interaction and challenges. Clin. Biomech. (Bristol, Avon), 29(4):36372, 2014. 
Gooyers, C. E. \& Callaghan, J. P. Exploring interactions between force, repetition and posture on intervertebral disc height loss and bulging in isolated porcine cervical functional spinal units from sub-acutefailure magnitudes of cyclic compressive loading. J. Biomech., 48(13):3701-8, 2015.

Hareni, N.; Strömqvist, F.; Strömqvist, B.; Rosengren, B. E. \& Karlsson, M. K. Predictors of satisfaction after lumbar disc herniation surgery in elderly. BMC Musculoskelet. Disord., 20(1):594, 2019.

Köksal, V.; Avnioglu, S. \& Atay, E. Is there effect of intervertebral disc herniation on the lumbar spine in early period? A morphometric and stereological study. Int. J. Morphol., 38(2):374-81, 2020.

Liu, Q.; Yang, X. P.; Li, K.; Yang, T.; Ye, J. D. \& Zhang, C. Q. Internal strains of anulus fibrosus in the intervertebral disc under axial compression load. Biomed. Res. (India), 28(8):3483-6, 2017.

O'Connell, G. D.; Vresilovic, E. J. \& Elliott, D. M. Human intervertebral disc internal strain in compression: the effect of disc region, loading position, and degeneration. J. Orthop. Res., 29(4):547-55, 2011.

Sapiee, N. H.; Thambyah, A.; Robertson, P. A. \& Broom, N. D. New evidence for structural integration across the cartilage-vertebral endplate junction and its relation to herniation. Spine J., 19(3):53244, 2019.

Schmidt, H.; Bashkuev, M.; Galbusera, F.; Wilke, H. J. \& Shirazi-Adl, A. Finite element study of human lumbar disc nucleus replacements. Comput. Methods Biomech. Biomed. Engin., 17(16):1762-76, 2014.

Schollum, M. L.; Wade, K. R.; Robertson, P. A.; Thambyah, A. \& Broom, N. D. A A Microstructural investigation of disc disruption induced by low frequency cyclic loading. Spine (Phila Pa 1976), 43(3):E13242,2018

Thoreson, O.; Ekström, L.; Hansson, H. A.; Todd, C.; Witwit, W.; Aminoff, A. S.; Jonasson, P. \& Baranto, A. The effect of repetitive flexion and extension fatigue loading on the young porcine lumbar spine, a feasibility study of MRI and histological analyses. J. Exp. Orthop., 4(1):16, 2017.

Vadalà, G.; Russo, F.; De Strobel, F.; Bernardini, M.; De Benedictis, G. M.; Cattani, C.; Denaro, L.; D’Este, M.; Eglin, D.; Alini, M.; et al. Novel stepwise model of intervertebral disc degeneration with intact annulus fibrosus to test regeneration strategies. J. Orthop. Res., 36(9):2460-8, 2018.

van Heeswijk, V. M.; Thambyah, A.; Robertson, P. A. \& Broom, N. D. Does an annular puncture influence the herniation path?: an in vitro mechanical and structural investigation. Spine (Phila Pa 1976), 43(7):467-76, 2018.

Veres, S. P.; Robertson, P. A. \& Broom, N. D. ISSLS prize winner: how loading rate influences disc failure mechanics: a microstructural assessment of internal disruption. Spine (Phila Pa 1976), 35(21):1897-908, 2010.

Wade, K. R.; Schollum, M. L.; Robertson, P. A.; Thambyah, A. \& Broom, N. D. A more realistic disc herniation model incorporating compression, flexion and facet-constrained shear: a mechanical and microstructural analysis. Part I: Low rate loading. Eur. Spine J., 26(10):2616-28, 2017

\author{
Corresponding author: \\ Chunqiu Zhang \\ School of Mechanical Engineering \\ Tianjin University of Technology \\ Tianjin 300384, \\ PR CHINA
}

Email: 13012251281@126.com

\section{Kun Li}

Tianjin Key Laboratory of Film Electronic and Communication

Device

Tianjin University of Technology

Tianjin 300384

PR CHINA

Email: likun_tjut@163.com

Received: $15-05-2020$

Accepted: 17-06-2020 